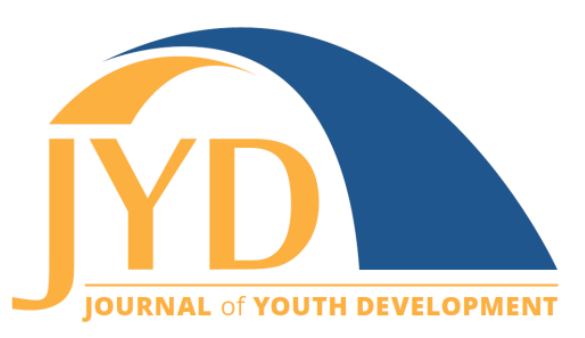

http://jyd. pitt. edu/ | Vol. 14 Issue 2 DOI 10.5195/jyd.2019.764 | ISSN 2325-4017 (online)

\title{
Turkish Delight
}

\section{Zahra Abdifatah Ali}

\begin{abstract}
Immersion as an international traveler to Turkey and experiencing the religion, culture, people, foods and lifestyle of the culture can have a life changing effect on youth. The youth author shares that providing authentic experiences and diverse opportunities is important in maximizing the potential.
\end{abstract}

Key words: youth leadership, Turkish culture, Islam

Late last summer my father pulled me aside and informed me of an opportunity to go on a trip to Turkey with a nonprofit organization, Open Path Resources. The goal of the trip was to have youth leaders from across the globe learn about where Islam came from, and how its history affects us. We intended to learn how Islam spread throughout the world from its roots, and bring that information back to share with our communities.

I was incredibly fortunate to have this opportunity, and while I was there I learned and experienced through the people and sites a peaceful, yet powerful way of life. Throughout our trip I felt a serenity among the Turkish people that made me feel at home. It was only after returning that I realized the Turkish people have a profound understanding of themselves and established a way of life that honors their history and continues to forge into the future.

Before this trip, I had never met the people I was traveling with or experienced Turkish culture beyond photos of the Blue Mosque I had seen online. On our first night there we went to a nearby restaurant to eat. While eating I heard the call to prayer, or "adhan" fill the air. It wasn't from just one mosque; all the mosques nearby had their own "muezzin," the man who reads the adhan. I was overwhelmed by the sound of so many beautiful voices calling to prayer, it felt like the first time I had ever heard the adhan and truly felt its impact.

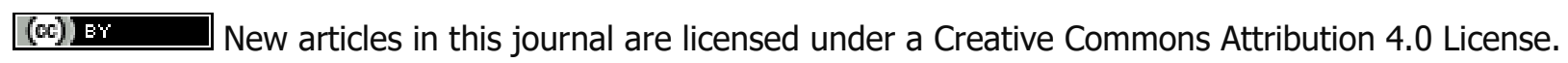
This journal is published by the University Library System, University of Pittsburgh and is cosponsored by the University of Pittsburgh Press. The Journal of Youth Development is the official peer-reviewed publication of the National Association of Extension 4-H Agents and the National AfterSchool Association. 
The many voices mixing together felt like one of those moments you want to freeze and capture in a bubble to keep forever. I soon learned that was normal in Turkey and every time we heard the call after that, I felt a wave of peace and deep connection to something greater than myself. Back home, the adhan is usually done by an older male relative, or if we are in a mosque, a muezzin, but those times are few and far between. With my busy schedule, oftentimes all I have is a pre-recorded adhan from my phone.

When I heard the adhan and saw that people stopped what they were doing right then and there to pray, I was amazed at how an entire country maintained their schedules and included time to not only pray, but also to reflect on their prayer and truly connect to the religion. As our trip progressed, each call we'd hear was more beautiful than the last. Hearing the adhan before each prayer made me realize that as a Muslim I am part of a much larger whole, and that it didn't matter where I came from or what I looked like. At a mosque, I was welcome. I felt more personally connected to my religion, and I was inspired to strive to create spaces that recreate that feeling back home.

The Turkish people we encountered were also very welcoming. When we were in the bazaars or on the streets, people would greet us and ask us how we were enjoying Turkey. I remember when we went to the Hagia Sofia (formerly a mosque; now a museum), a few of the Turkish college students that were helping show us around took us to an ice cream shop nearby. They helped translate between us and the people we met. They explained how mosques operate. They showed us around these beautiful neighborhoods and introduced us to some well-known locals. Once we entered the ladies' area of a mosque, it was a while before we were to pray. While waiting, the students helped translate between an older woman and me, and she explained her experience having the time to come to a mosque for every prayer. That particular conversation made me realize that I can do everything - being a Muslim while having a lively schedule is possible-and I was inspired to achieve the tranquility I found in Turkey back home.

Being with the Turkish students taught me that that level of kindness isn't something that should be reserved for the people you're closest with. We hadn't known them for longer than a day, yet they laughed and talked with us like old friends. They took us by this beautiful street tucked away near a mosque with these umbrellas hanging on a line above. The light filtered through the colored cloth and made the whole scene magical. There we met a famous local who raises chickens. She welcomed us to Turkey and explained to us the history of that street 
Turkish Delight

like she was recounting an old story with friends. That experience has really made me realize that that community brings us together, no matter how long we've known one another.

There were lessons I learned from buildings too. Many of the mosques we visited had a marble slab on the entrance that was curved and worn with the weight of the people who had visited it. I remember at the first mosque we visited, the Süleymaniye Mosque, the marble had a huge dip right where people had stepped, and it made me think about the hundreds of thousands of people that had visited and slowly worn it down, and how my own footsteps contributed to it. I imagined all the possible historical figures that could have passed through, and all the future youths and travelers that would leave their marks.

I learned while sharing meals with my fellow travelers that the world is enormous, but we're all connected by something. It could be a coincidence, fate, or Allah's will, but through our conversations while dining or on bus rides I became fast friends with my fellow travelers. We developed a saying, "In Turkey we make bold moves," and we want to continue that here in Minnesota.

From a woman we called Abla, which translates to "big sister" in Turkish, I learned that language is only as big a barrier as you allow it to be. She was the wife of the bus driver we had for part of the trip, and although she didn't speak English, we learned a few Turkish words and phrases and used a lot of gesturing to have a conversation. She was warm and kind with us and I'm grateful for all the help she gave us while there.

When we visited Yunus Emre Institute's building in Ankara, we had conversations with the president of the Institute about our position as the leaders of tomorrow, and how our trip had affected us, and our future plans when we return. That conversation is when I realized that the trip is going to be a lot more than just going to Turkey. Being in the midst of so much Islamic history inspired me to spread what I've learned within my community by sharing photos of inscriptions at monuments and doing more research into Islam after the Four Rightly Guided Caliphs. Now that I'm back I want to share the life lessons I learned in Turkey with my family and the Muslim community in Minnesota, so we can all improve and make life as a Muslim in America better for ourselves and for future generations. 